\title{
LIPID COMPOSITION OF BUFFALO SPERMATOZOA: A CYTOCHEMICAL AND BIOCHEMICAL STUDY
}

\author{
S. S. GURAYA AND K. S. SIDHU \\ Department of Zoology, College of Basic Sciences and Humanities, \\ Punjab Agricultural University, Ludhiana, Punjab, India
}

(Received 2nd Fuly 1974)

\begin{abstract}
Summary. Buffalo spermatozoa have been studied cytochemically and biochemically to investigate their phospholipids, which appear to be phosphatidyl choline, lysolecithin, phosphatidyl ethanolamine, phosphatidyl inositol, phosphatidyl glycerol and monogalactosyl diglyceride. Most of them form lipoprotein complexes in the regions of the plasma membrane, the post-nuclear cap and the mid-piece. The lipid composition of buffalo spermatozoa has been compared to and contrasted with that of bull and ram spermatozoa and species differences are indicated.
\end{abstract}

Lipids are believed to determine the barrier properties of natural membranes. Knowledge of the rôles of lipids in the physiology of spermatozoa is still very meagre (see Mann, 1964), and it would be useful to know the lipid composition of the spermatozoa of different species. Studies on the spermatozoa of the ram, bull and man (Hartree \& Mann, 1961; Masaki \& Hartree, 1962; Pursell \& Graham, 1967; Scott \& Dawson, 1968; Poulos \& White, 1973) have revealed conspicuous differences. In the present study, a qualitative analysis has been made of the phospholipids of buffalo spermatozoa and an attempt has also been made, using cytochemical techniques, to determine the sites where the lipids are present. The study is part of a wider investigation into the development of a suitable extender for buffalo semen.

Semen was collected from sexually mature buffalo bulls (Bubalus bubalis) of known fertility using an artificial vagina. Three to four ejaculates were pooled to make the final volume to nearly $10 \mathrm{ml}$. Semen was kept at $4^{\circ} \mathrm{C}$ for 10 to $15 \mathrm{~min}$ in order to immobilize the spermatozoa. Spermatozoa were separated from seminal plasma by centrifugation. The sperm pellet was washed with phosphate buffer at $\mathrm{pH} 7.4$ three times and was again centrifuged. The washed spermatozoa were shaken with $20 \mathrm{ml}$ chloroform:methanol $(2: 2$, $\mathrm{v} / \mathrm{v}$ ). The solution was boiled for $45 \mathrm{~min}$ in a flask fitted with a condenser to avoid loss of solvent, and was then filtered through a sintered funnel and purified by the method of Folch, Lees \& Sloane-Stanley (1957). The purified extract was evaporated.

Lipids were fractionated on a silica gel column by the method of Ramsey \& 
Pattersen (cited in Pursell \& Graham, 1967). Chloroform:methanol:acetic acid $(65: 35: 4$, by vol.) was used as solvent for polar lipids. Lipids were visualized by the Dragandroff reagent and $\mathrm{I}_{2}$. Calculated $R_{\mathrm{F}}$ values were compared with standard $R_{F}$ values.

For the cytochemical localization of lipids, smears of diluted buffalo semen were fixed and postchromed by the method of Baker (1957). After washing, the smears were stained with Sudan black B, Nile blue and acid haematein (see Pearse, 1968). Smears were also processed by the Sudan black B method for masked lipids of Ackerman (1952; cited in Pearse, 1968).

The various phospholipids found are shown in Table 1. The lipids in the petroleum jelly, i.e. petroleum hydrocarbon (Pursell \& Graham, 1967), which was used to lubricate the artificial vagina, were taken into consideration.

Table 1. The phospholipids of buffalo spermatozoa compared with those of the bull and ram (+, present; -, absent)

\begin{tabular}{l|c|c|c}
\hline \multicolumn{1}{c|}{ Lipids } & Buffalo & Bull* & Ram $\dagger$ \\
\hline Phosphatidyl choline & + & + & + \\
Lysolecithin & + & - & - \\
Phosphatidyl ethanolamine & + & \pm & + \\
Phosphatidyl inositol & + & - & \pm \\
Phosphatidyl glycerol & + & - & - \\
Monogalactosyl diglyceride & \pm & - & + \\
Sphingomyelin & \pm & \pm & + \\
Phosphatidyl serine & - & - & + \\
Cardiolipin & - & + & + \\
Plasmalogen & - & - & + \\
\hline
\end{tabular}

* From Pursell \& Graham (1967).

$\uparrow$ From Scott, Voglmayr \& Setchell (1967).

The cytochemical reactions of the different parts of the spermatozoa are summarized in Table 2. The mid-piece and the post-nuclear cap areas were moderately positive for lipids, which consisted mainly of phospholipids, most of which appeared by the Ackerman method to be masked with protein to form lipoproteins. No lipids could be demonstrated in the acrosomal cap and nucleus, and no reactions in the thin plasma membrane could be seen by the light microscope.

Buffalo spermatozoa resembled those of the bull in their contained lipids except that sphingomyelin was not found in the former (Table 1). It appeared that the various phospholipids found were combined with proteins to form lipoprotein complexes, since very little free phospholipid could be demonstrated in the different parts of the spermatozoa. Recent biochemical studies have shown that different phospholipids are involved in the chemical composition of biological membranes (see Tria \& Scanu, 1969). It can therefore be presumed that the various phospholipids demonstrated in buffalo spermatozoa must be membrane components. Membrane structure is very labile and thus various kinds of lipids, e.g. saturated, unsaturated and cholesterol, may in- 
fluence the characteristics of sperm lipoprotein membranes as there is, in general, a close relationship between lipid composition and the permeability of membranes (Van Deenen, DeGier \& Demel, 1972). Since the sperm phospholipids differ in the buffalo and in the ram and bull, it is inferred that the membrane structures of the spermatozoa of these species must also be different.

Table 2. The cytochemical reactions of different parts of buffalo spermatozoa

\begin{tabular}{|c|c|c|c|c|c|c|c|c|}
\hline \multirow[b]{2}{*}{ Technique* } & \multirow[b]{2}{*}{ Fixation } & \multicolumn{3}{|c|}{ Head } & \multicolumn{3}{|c|}{ Tail } & \multirow[b]{2}{*}{ Remarks } \\
\hline & & $\begin{array}{l}\text { Acro- } \\
\text { some }\end{array}$ & Nucleus & $\begin{array}{c}\text { Post- } \\
\text { nuclear } \\
\text { cap }\end{array}$ & $\begin{array}{l}\text { Mid- } \\
\text { piece }\end{array}$ & $\begin{array}{l}\text { Main } \\
\text { piece }\end{array}$ & $\begin{array}{r}\text { End } \\
\text { piece }\end{array}$ & \\
\hline $\begin{array}{l}\text { 1. Sudan black B } \\
\text { in } 70 \% \text { ethanol }\end{array}$ & $\mathrm{FGA}+\mathrm{PG}$ & - & - & + & ++ & - & - & $\begin{array}{l}\text { Lipids in post-nuclear cap and } \\
\text { mid-piece }\end{array}$ \\
\hline $\begin{array}{l}\text { 2. Sudan black B } \\
+P E\end{array}$ & $\mathrm{WB}+\mathrm{PE}$ & - & - & - & - & - & - & $\begin{array}{l}\text { Confirming lipids in the post- } \\
\text { nuclear cap and mid-piece }\end{array}$ \\
\hline 3. Acid haematein & $\mathbf{F C A}+\mathbf{P C}$ & - & + & + & ++ & - & - & $\begin{array}{l}\text { Some free phospholipids in post- } \\
\text { nuclear cap and mid-piece }\end{array}$ \\
\hline $\begin{array}{l}\text { 4. Acid haematein } \\
+\mathrm{PE}\end{array}$ & $\mathrm{WB}+\mathrm{PE}$ & - & + & - & - & - & - & $\begin{array}{l}\text { Confirming free phospholipids in } \\
\text { the post-nuclear cap and mid- } \\
\text { piece; positive reaction of } \\
\text { nucleus is due to nucleoprotein } \\
\text { component }\end{array}$ \\
\hline 5. Nile blue & $\mathrm{FGA}+\mathrm{PG}$ & $\mathrm{B}^{+}$ & $\mathrm{B}^{++}$ & $\mathrm{B}^{+++}$ & $\mathrm{B}^{+++}$ & $\mathrm{B}^{++}$ & $\mathrm{B}^{+}$ & $\begin{array}{l}\text { No neutral lipids; blue reaction } \\
\text { is due to protein, lipoprotein } \\
\text { and nucleoprotein }\end{array}$ \\
\hline $\begin{array}{l}\text { 6. Sudan black } \\
\text { B after } 25 \% \\
\text { acetic acid }\end{array}$ & $\begin{array}{r}\text { Formalin } \\
\text { vapour }\end{array}$ & - & - & ++ & +++ & - & - & $\begin{array}{l}\text { Lipids in post-nuclear cap and } \\
\text { mid-piece unmasked }\end{array}$ \\
\hline
\end{tabular}

FCA, formaldehyde calcium; PG, dichromate calcium; WB, weak Bouin; PE, pyridine extraction; B, blue reaction; + , moderate reaction; ++ , strong reaction; +++ , very strong reaction; - , negative reaction.

* Technique 1 from Baker (1957), 2, 3 and 4 from Baker (1946), 5 and 6 from Pearse (1968).

Jones (1973) has made a similar suggestion on the basis of an ultrastructural study of the spermatozoa of the ram, boar and bull. Understanding of the different phospholipid compositions of sperm membranes may be important for determining suitable semen extenders for the various species.

Thanks are due to Dr F. S. Chauhan and Mr O. P. Takkar for help in obtaining the buffalo semen.

\section{REFERENCES}

BAKER, J. R. (1946) The histochemical recognition of lipin. Q.F. microsc. Sci. 87, 441-470.

BAKER, J. R. (1957) Improvement in the Sudan black technique. Q.J. microsc. Sci. 97, 621-623.

Folch, J., Lees, M. \& Sloane-Stanley, G. H. (1957) A simple method for the isolation and purification of total lipids from animal tissues. 7. biol. Chem. 226, 497-509.

Hartree, E. F. \& MANN, T. (1961) Phospholipids in ram semen: metabolism of plasmalogen and fatty acids. Biochem. 7. 80, 464-476.

JoNes, R. C. (1973) The plasma membrane of ram, boar and bull spermatozoa. F. Reprod. Fert. 33, $179-183$.

Mann, T. (1964) The Biochemistry of Semen and of the Male Reproductive Tract. Methuen, London. 
MASAKi, J. \& HARTrEe, E. F. (1962) Distribution of metabolic activity, phospholipid and hyaluronidase between the heads and tails of bull spermatozoa. Biochem. F. 84, 347-353.

Pearse, A. G. E. (1968) Histochemistry, Theoretical and Applied. Churchill, London.

Pouros, A. \& Write, I. G. (1973) The phospholipid composition of human spermatozoa and seminal plasma. F. Reprod. Fert. 35, 265-272.

Pursell, V. G. \& Graham, E. F. (1967) Phospholipids of bovine spermatozoa and seminal plasma. F. Reprod. Fert. 14, 203-211.

Scotr, T. W. \& Dawson, R. M. C. (1968) Metabolism of phospholipids by spermatozoa and seminal plasma. Biochem. F. 108, 457-463.

Scott, T. W., Voglmayr, J. K. \& Setcheli, B. P. (1967) Lipid composition and metabolism in testicular and ejaculated ram spermatozoa. Biochem. F. 102, 456-461.

TRIA, E. \& SCANu, A. M. (1969) Structural and Functional Aspects of Lipoproteins in Living Systems. Academic Press, London.

Van Deenen, L. L. M., DeGier, J. \& Demer, R. A. (1972) Relations between lipid composition and permeability of membranes. In Proc. Int. Symp. Lipids, Bangalore, pp. 377-382. Eds. J. Ganguly and R. M. S. Smellie. Academic Press, London and New York. 